\title{
RUSLAND'S MUNTHERVORMING.
}

E. Lorinı. La Réforme monétaire de la Russie. Traduction française par R. LEDOs DE BEAJfoRT avec préface de R. G. Léry. Paris 1898.

R. LEDos de Beatfort. L'achèvement et l'application de la Réforme monétaire de la Russie. Préface de A. Raffalovich. Paris 1899.

Dr. G. v. ScRULZE-GäVERNITz. Volkswirtschaftliche Studien aus Russland. Hoofdstuk VI. Zur Währungsreform. Leipzig 1899.

Drie jaren zijn thans verloopen sedert, na langdurige voorbereiding, een begin vau uitvoering werd gegeven an de munthervorming vau Rusland, en ruim twee jaren sedert deze door de ukase van 14 November 1897 haar beslag kreeg. Slechts enkele aanvullende regelingen moesten daarna nog volgen, hetgeen in 1898 geschiedde.

In het afgeloopen jaar is de nieuwe orde van zaken aan een harde proef blootgesteld geweest. De spanning, die in de laatste maauden des jaars geheerseht heeft aan alle Europeesche geldmarkten, deed zich met bijzondere heftigheid in Rusland gevoelen. Toch heeft de Russische wisselkoers geen abnormale afwijkingen van het goudpunt vertoond. De noteering van den roebelkoers te Berlijn was in 1899 als minimun 216 Mk 216 per Rb 100) evenals in de twee voorgaande jaren; als maximum 217.15 tegen 217.80 in 1898 en 218 in 1897; gemiddelde koers 216.37 tegen 216.48 en 216.69 .

Het oogenblik zal daarom wel niet ongeschikt te achten zijn om eens nader de aandacht te vestigen op die munthervorming en op hare beteekenis in verband met de economische ontwikkeling van het rijk.

Het beginsel waarop de munthervorming moest berusten werd in Juni 1887 vastgesteld door het Financieele Comité, ECON. 1900. 
dat op last van den Keizer, Alexander III, zich met het onderzoek van het vraagstuk had bezig gehouden. Op 's Keizers bevel was door den sedert 1 Januari van dat jaar opgetreden Minister van Financien, Vychnegradsky, aan het comité de volgende vraag voorgelegd: Moet het streven wezen de waarde vau den kredietroebel langzamerhand op te voeren tot de pariteit van den goudroebel en die daarop te handhaven, of zal het doel wezen den kredietroebel te consolideeren op zijn tegenwoordige waarde en op dien voet de speciebetalingen te hervatten? In overeenstemming met de meening van den minister werd de vraag in den laatstbedoelden zin beslist, en daarbij werd door den minister de wensch uitgesproken om te komen tot eene definitieve waardeverhouding van één en een halven kredietroebel gelijk aan é́n goudroebel. Luid zijn eigenhandig bijschrift "A exécuter" werd die beslissing door den Keizer goedgekeurd. ${ }^{1}$ )

Nochtans werdt het alzoo genomen besluit niet aanstonds bekend gemaakt. Eerst einde 1896, in het rapport aan den Keizer dat jaarlijks door den Minister van Finaneien bij de Begrooting voor het volgend jaar wordt overgelegd, geschiedde dit door minister de Witte, die sedert 30 Augustus 1892 aan Vychnegradsky was opgevolgd.

Dank zij de maatregelen, sedert 1887 door de twee genoemde ministers genomen om de munthervorming uitvoerbaar te maken, was eindelijk in 1896 het oogenblik aangebroken dat die ondernomen kon worden, en de heer de Wittel wenschte toen niet na te laten aan den overleden keizer de eer te geven van de oorspronkelijke ontwerper der regeling te zijn geweest.

De eigenlijke munt-eenheid van Kusland was nog altijd de zilveren roebel van, volgens de wet van 17/29 December 1885 , 20 gram $900 / 1000^{\text {ste }}$ fijn; - te voren, volgens de wet van 1810,20735 gram $868 / 1000^{\text {ste }}$ fijn. Daarnaast stonden vroeger als gouden muntstukken de oude halve imperialen van $6^{554}$ gram $916 \frac{2}{3} / 1000^{\text {ste }}$ fijn, nominaal gelijk aan 5.15 roebel; en sedert de wet van 1885, in werking getreden

1) Cf. Lorini. La Réforme monétaire de la Russie. bl. 118/9. A Raffalovich in L'Economiste français, 1897, bl. 71 en de Foville. Muntverslag 1897, bl. 189/90. 
1 Januari 1886, de heele en halve imperialen van $12^{904}$ en $6^{5+2}$ gram $900 / 1000^{\text {ste }}$ fijn, nominaal gelijk aan 10 en 5 roebel. Maar alhoewel, dagteekeneude van den tijd dat de verhouding van $1: 15 \frac{1}{2}$ tamelijk algemeen als de pariteit der twee edele metalen werd beschouwd, deze nominale roebelwaarde voor de gouden muntstukken werd aangenounen, is het goud vóór de nieuwe munthervorming nooit standaardmunt geweest in Rusland en waren de oude en nieuwe imperialen er niets anders dan handelsmunt. Het is een punt waarop wij nader terug te komen hebben.

Naast den zilveren roebel heeft intusschen steeds gestaan het papierengeld en in de werkelijkheid heeft dit altijd de hoofdrol gespeeld in den geldomloop. Slechts in de jaren 1843 tot 1856 is de zilveren roebel waarlijk standaard-munt geweest in de praktijk, gelijk toen de staatsbilletten niet alleen volgens de letter der wet maar ook feitelijk inwisselbaar waren. Doch tengevolge der aanzienlijke uitgiften vau billetten welke door den Krim-oorlog veroorzaakt werden, nam die inwisselbaarheid in 1855 weder een einde en weldra daalde de koers verre onder de pariteit der zilver-waarde van den roebel, gelijk later nog meer onder den invloed der vernieuwde nitgiften vau papier waartoe de oorlog van $1877 / 78$ aanleiding gaf. Eerst met het optreden van den heer Bunge als Minister van Financien, in 1881 , kwam er een begin van verbetering in den toestand. Doch het zou tot $1896 / 97$ duren, dat het papierengeld als eigenlijk betaalmiddel dienst moest doen en de warde van den roebel af hankelijk bleef van de hoeveelheid billetten die in omloop waren en van de vooruitzichten of verwachtingen ten aanzien hunner eventueele inwisseling.

Nochtans heeft in den loop dier jaren de toestand eene zeer gewichtige wijziging ondergaan. De papieren- of kredietroebel werd namelijk door de regeering losgemaakt van zijne theoretische waardeverhouding tot het zilver. Reeds in 1876 werd door den Minister van Financiën de Reutern de vrije zilveranmunting voor particulieren geschorst. En klaarblijkelijk is het van den aanvang af zijne bedoeling geweest, gelijk ook zijn opvolgers aan dit denkbeeld bleven vasthouden, dat wanneer Rusland tot hervatting der specie-betalingen zou kunnen overgaan, dit niet geschieden zou met terugkeer tot den zilveren standaard maar 
met overgang tot den gouden. 1) Zoo werd dan ook, toen in 1893 door de daling van den goudprijs van het zilver de waarde-pariteit was hersteld tusschen den papieren- en den zilveren roebel en Rusland tot de specie-betalingen had kunnen terugkeeren eenvoudig door de zilveraanmunting weder voor het publiek open te stellen, hiertoe niet overgegaan. Integendeel, uitdrukkelijk was reeds per decreet van 12 Maart 1892 de schorsing der vrije zilveraanmunting gehandhaafd. Fn evenmin als de regeering de gelegenheid tot zilveraanmunting voor particuliere rekening wilde heropeuen, wilde zij deze voor eigen rekening hervatten. Tevens ging zij door, gelijk onder de Reutern was aangevangen, slechts goud op te zamelen tot warborg der circuleerende billetten.

$\mathrm{Zij}$ bleef trouwens, aldus handelende, slechts getrouw aan het hierboven besproken besluit van 1887, dat echter op het tijdstip dat wij nu bespreken - de eerste negentiger jaren nog niet bekend was gemaakt. Immers daardoor was uitgemaakt dat de hervatting der specie-betalingen zou geschieden met goud als standaardmunt, alleen nog het onbeslist gelaten zijnde welke de juiste waarde van den goudroebel zou zijn. ${ }^{2}$ )

1) Cf. Lorine t. a. p. Hfds. III $\$ 13$.

2) Het mag hier de plaats geacht worden om melding te maken van hetgeen door Lorini in het eerste hoofdstuk van zijn werk is geschreven over de wijsheid van het besluit der Russische regeering ter overgang tot den gouden standaard in plaats van terugkeer tot den zilveren standaard. Hij doet het namelijk voorkomen alsof dit laatste verlangd werd door de bimetallisten, les s o i-dis ant bi métallistes ou monométallistes blancs, zooals hij ze noemt; bewerende dat door hen van Rusland verlangd werd terugkeer tot het zilver, ten einde den goudprijs van dit metaal te doen stijgen en daardoor hun zaak te berorderen. Welnu, of dit van enkele zijden gewenscht werd, hlijve in het midden. Maar het standpunt der eigenlijke bimetallisten in en buiten Rusland was het niet. Wat door hen gewenscht werd is, dat Rusland zich bereid verklaard zou hebben toe te treden tot eene internationale bimetallieke conventie onder verbintenis om dan zijnerzijds den tweeledigen standaard aan te nemen bij de hervatting der specie-betalingen. Beweerd werd daarbij dat dit, ten leenre, die hervatting der specie-betalingen vergemakkelijkt zou hebben; ten andere, voor Rusland, dat niet minder aanzienlijke handelsverbindingen heeft met de zilverlanden van het Oosten dan met de goudlanden van het Westen, nog een 
De feitelijke toestand was op het einde van 1896 de volgende geworden. Tegenover een aan billetten nitstaand bedrag van 1121 millioen roebels stond in de Schatkist en bij de Staatsbank te zamen een werkelijke goudvoorraad van 804 , millioen goudroebels, zegge roebels van een tiende imperiaal. De munthervorming uitgevoerd wordende op den voorgenomen grondslag, zouden deze 804 , millioen goudroebels uitmaken 1206 kredietroebels of nieuwe roebels goud. De totaalsom der uitstaande billetten was aldus volledig in goud gedekt en meer dan dat.

De regeering achtte nu het oogenblik gekomen óm de munthervorming tot stand te brengen. 'Te meer achtte zij dat dit zonder bezwaar kon geschieden, omdat bij decreet van 22 Augustus 1896 de koers van den ouden goudroebel in kredietroebels reeds voorloopig en dat wel aanvankelijk tot 1 Januari

bijzonder voordeel zou hebben opgeleverd. Nog altijd mag die redeneering verdedigd worden als volkomen juist te zijn geweest. Zeker, Rusland heeft het internationale bimetallisme niet noodig gehad om aan het régime van het papierengeld te ontkomen; maar de buitengewoon sterke vermeerdering der goudproductie van de allerlaatste jaren was ook zelfs in de eerste negentiger jaren nog niet te voorzien en het blijft de vraag, of Rusland zonder deze er zoo spoedig en zoo gemakkelijk in geslaagd zou zijn den noodigen goudvoorraad te verzamelen. En wat betreft Ruslands positie aà chevalı tusschen de zilverlanden van het Oosten en de goudlanden van het Westen, zoo is thans wel met de goudlanden rastheid van wisselkoers verkregen, niet echter met de genoemde zilverlanden. De grootste bezwaren daarvan zullen allicht eerst dan reeht ondervonden worden, wanneer de uitbreiding van Rusland's handel in het Oosten meer een roldongen feit zal zijn. En inmiddels levert reeds nu de geldhandel met Aziatisch Rusland geen geringe moeilijkheden op, gelijk blijkt uit de zeer belangrijke bijzonderheden dienaangaande die door Lorini zelf (Hfds IV \& 21) worden medegedeeld. Volgens hem zou de bedoeling der Russische regeering zijn aldaar langzamerhand het russische muntstelsel in te voeren; aangenomen dat dit uitroerbaar zal blijken, zou daaruit echter weder dit nadeel ontstaan, dat in die streken vooral het eig̀enlijke circulatieıniddel dan zijn zal de pasmunt. Hierıêe wil echter niet gezegd zijn, dat Rusland niet rerstandig gehandeld heeft den gouden standaard aan te nemen daar de houding der andere Europeesche landen, van Engeland vooral, het internationale bimetallisme onmogelijk maakte; alleen dit, dat voor Rusland inzonderheid het wel wenschelijk geweest ware, dat tot eene internationale bimetallieke conventie gekomen had kunnen worden. 
1898 op R. 1.50 was vastgesteld, alle openbare kassen gemachtigd wordende het goud op dien koers aan te nemen en de Bank om het op dien koers zoowel aan te nemen als af te geven; voorts, de Bank zich bereid verklaard hebbende in de verhoudin van dien koers ook vreemde gonden muntspecien in ontvangst te nemen, 65 millioen roebels goud in 1896 door het gewone handelsverkeer in Rusland waren ingevoerd. De geldbeweging in Russisch goud bij de Bank en de openbare kassen had in hetzelfde tijdsverloop bedragen 693 millioen goudroebels in uitgaaf en 668 in ontvangst. ')

Successivelijk verschenen nu de volgende ukasen:

Die van 3/15 Januari 1897, inhoudende dat aangemunt zouden worden nieuwe goudstukken in alles conform de bestaande imperialen en halve imperialen, maar vermeldeude de waardebepaling à 15 en $7 \frac{1}{2}$ roebels. Tevens werd te kennen gegeven, dat voor alle overeenkomsten te voren gesloten in goudroebels en voor de betaling der inkomende rechten of andere belastingen, waarvan de betaling in goud was voorgeschreven, de gemelde nieuwe goudstukken in ontvangst genomen zouden worden voor 10 en 5 goudroebels.

Die van 29 Angustus/16 September 1897, regelende de gouddekking der billetten. Bepaald werd, dat de billetten door de Bank worden uitgegeven, uitsluitend voor zooveel vereischt wordt ter voldoening an de behoeften der geldmarkt en door goud gewaarborgd zouden zijn. Met dien verstande dat het goud, strekkende tot dekking der billetten, in bedrag gelijk aan deze moet zijn voor de helft voor zoover de in circulatie gestelde billetten niet meer beloopen dan 600 millioen roebeì, en voor het geheel, zegge roebel per roebel, voor het meerdere bedrag, namelijk in de verhouding van één imperiaal per 15 kredietroebels.

Die van 14/26 November 1897, regelende de uitgifte van een nieuw goudstuk. Bepaald werd dat geslagen zouden worden goudstukken van 5 roebels, van gewicht en gehalte overeenkomende met een derde imperial (van gram $4.3012900 / 1000$ fijn.)

Tegelijkertijd werd besloten dat een wijziging gebracht zou

1) Cf. de Foville. Muntrapport 1897 bl. 190, en A Raffalovich. Le Budget Russe de 1897, in L'Economiste Francais, 1897. I bl. 71 v. 
worden in den vorm van de balaus der Staatsbank. Tevoren was deze gesplitst in twee onderdeelen: een betreffende het zoogenaamde dekkingsfonds der billetten, het andere betreffende de handelsoperatien der Bank. Voortaan zou die verdeeling vervallen, de billetten opgevoerd blijvende in het passief der bank, daarentegen de goudvoorraad en de schuld van de Schatkist voorkomende onder het actief. Tevens werd de goudvoorraad, tot op dien datum vermeld als oude goudroebels, geconverteerd in kredietroebels.

Bij een tweede ukase van denzelfden datum werd de tekst der billetten in overeenstemming gebracht met de nieuwe regeling van zaken. In aansluiting aan de ukase van 3 Januari 1897, waarbij de waarde van den imperiaal en die van den halven imperiaal op 15 en 7,50 roebel was gesteld, werd bepaald dat de billetten voortaan de verplichting zouden inhouden der inwisseling tegen goud naar den maatstaf van éen roebel per $1 / 15^{\text {d }}$ imperiaal. Voorts was daarop te vermelden, dat de inwisseling der billetten tegen goud wordt gewaarborgd door alle middelen van den Staat; alsmede, dat de billetten door het geheele keizerrijk wettig betaalmiddel zijn in pariteit met het goudgeld.

Ten slotte is bij ukase van 27 Marrt/8 April 1898 de uitgifte van het zilvergeld geregeld.

Reeds in 1895 was aangevangen met de aanmunting van heele, halve en kwart roebel-stukken tot een aanzienlijk bedrag, opdat in de behoefte aan pasmunt ter vervauging van kleine billetten voorzien zou worden. Looals bekend is, werd met die aanmunting ook de Fransche Munt voor een deel belast. Thans werd bepaald dat de totaalsow dezer pasmunt, met inbegrip van de kleinere stukken, van 20,15, J0 en 5 kopeks, niet meer zou mogen bedragen dan 3 roebel per hoofd der bevolking. Voorts, dat het maximum bedrag wartoe de pasinunt in betaling noet wordeu aaugenomen is 25 roebel, terwijl bij de betaling der tolrechten of andere in goud te betalen belastingen dit betaalmiddel tot geen hooger bedrag dau 5 roebel dienst mag doen.

Tevens werd bepaald dat vourtaan de roebel van $1 / 15^{\text {de }}$ imperial de eenige reken-eenheid zou zijn.

Nader, bij ukase van 11/23 December 1898 is nog tot de 
uitgifte van een goudstuk van 10 roebels besloten, zijnde dit stuk in gewicht het dubbele van het 5 roebelstuk.

En eindelijk is bij de wet van 7/19 Juni 1899 de geheele muntregeling gecodificieerd. ')

Twee vragen stellen zich van zelf ten aanzien der muutregeling.

Ten eerste, of de bepaling, dat 15 kredietroebels in waarde slechts gelijk gesteld werdeu met 10 oude goudroebels, wel rechtmatig was?

Ten tweede, of de regeling de noodige waarborgen aubiedt van duurzaaınheid?

Wat betreft de rechtmatigheid der regeling, zoo blijkt het wel dat die door de Russische regeering zelve geeu oogenblik betwijfeld is.

Tweeërlei beweegredenen golden voor de regeering om door herstel der specie-betalingen aan de schommelingen van den wisselkoers een einde te maken. Daarbij toch was gemoeid het algemeen belang in de waardevastheid van het betaalmiddel; en daarnanst stond het direkte belang der Schatkist met het oog op het aanzienlijke bedrag der goudschulden van den Staat.

Die goudschulden nu waren aangegaan in buitenlandsche valutas, en in zooverre zou het in het voordeel van de schatkist zijn geweest de waarde vau den roebel zooveel mogelijk op te voeren, liefst tot de oude pariteit van 10 kredietroebels gelijk aan één inperiaal. Maar deze consideratie heeft bij de Russische regeering niet gewogen. Minister de Witte heeft bet in zijn rapporten aan den Keizer uitdrukkelijk gezegd: het streven moest slechts wezen, om door de munthervorming zoo min mogelijk verstoring in de bestaande geldelijke verhoudingen en verplichtingen te doen ontstaan, niemand kunstmatig te verrijken noch te verarmen.

Daarom moest de regeling zich aansluiten aan den bestaauden stand van zaken, deze eerst door doeltreffende maatregelen zooveel mogelijk stabiel gemaakt zijnde, niet daarin eerst verandering gebracht wordende. Vó́r den laatsten oorlog, dien van 1877, had men zich kunnen vleien met het denkbeeld

1) Men vindt de officieele fransche vertaling van deze wet in de Forille's Muntverslag van 1899. 
om den roebel weder op zijn oude goudwaarde op te voeren; maar later hadden alle prijzen zich gesteld in verband met de waarde toen door deu kredietroebel verkregen. Met dien stand van zaken moest nu rekening gehouden worden. Van daar de vaststelling van de waarde van den roebel op én imperiaal gelijk 15 kredietroebels, eene verhouding overeenkomende met den gemiddelden wisselkoers van den lateren tijd.

Het was dus louter de economische en financieele zijde van het vraagstuk waaamede de regeering zich heeft bezig gehouden; een rechtskwestie leverde het volgens hare opvatting blijkbaar niet op.

Het heeft echter, voornamelijk in Rusland zelf, niet aan bestrijders van de juistheid van dit standpunt ontbroken Men heeft zelfs van enkele zijden niet geaarzeld de muntregeling een vermomd staatsbankroet te noemen.

$\mathrm{Zij}$ die aldus oordeelden konden wel niet ontkenuen, dat oorspronkelijk de russische roebel uitslnitend een zilver-roebel is geweest en dat vroeger de regeering zich wel het recht had voorbehouden de billetten in goud in te wisselen - destijds op den voet van één imperiaal voor 10 roebels - maar danrtoe nooit verplicht was geweest, terwijl, had de regeering zich gehouden aan de zilverwaarde van den roebel, dit cle houders van de billetten en van alle vorderingen in roebels in veel ongunstiger toestand zou hebben gebracht. Maar zij beweerden dat, niet alleen de regeering door de zilver-aanmuntingen te sehorsen de waarde van den kredietroebel geheel had losgemaakt van het verband met de zilverwaarde, doch ook, door later te bepalen dat de betalingen in goud, bepaaldelijk ter voldoening der jnkomende rechten, moesten geschieden op den voet van één imperial voor 10 roebels, de theoretische waarde van den roebel aldus had vastgesteld, en hierop thans niet meer terug gekomen mocht worden zonder inbreuk te maken op de goede trouw.

Zeer belangrijk is de uitvoerige verdediging van de tegenovergestelde stelling door Lorini in de drie eerste hoofdstukken van zijn boek en bepaaldelijk in het tweede en derde. Wij kunnen den belangstellenden lezer daarnaar slechts verwijzen; het zou ons veel te ver voeren deu schrijver te volgeu. Volstaan wij hier met aan te teekenen, dat hij zich voornamelijk ten doel heeft gesteld aan te toonen, dat Rusland vóór 1897 geen 
andere munt-eenheid heeft gehad dan de zilveren roebel. Bij de uitgifte der nieuwe krediet-billetten, wordt door hem herinnerd, werd uitdrukkelijk geconstateerd dat deze gangbaar zouden zijn in de pariteit van het wettige zilveren betaalmiddel. En nu zou, wel is waar, later de vrije zilveraanmunting geschorst zijn en dit hebben plaats gevonden met het roornemen om te komen tot den overgang van den zilveren tot den gouden standaard, nergens en nooit echter de bestaande gouden muntstukken, de oude halve imperialen, of later de volgens de wet zan 1885 aangemunte heele en halve imperialen, als standaardmunt zijn erkend. De voet waarop later de overgang ran den zilveren op den gouden standaard moest geschieden, bleef voor nadere beschikking voorbehouden; direkt noch indirekt zou dienaaugaande de regeering zich ooit aan banden hebben gelegd.

Dezelfde meening wordt voorgestaan door Von SchulzeGävernitz. Volgens de wet, zegt deze, was de kredietroebel eukel vertegenwoordiger van zilver totdat de munt voor de vrije zilver-aanmunting werd gesloten. En daarna heeft de kredietroebel wel een waarde verkregen welke verband hield met die van het goud, maar deze verhouding werd bepaald loor de vraag en het aanbod van den wissel op Londen te Petersburg of door de waarde in Duitsch goud door de beurs te Berlijn aan den kredietroebel toegekend. M. a. w. de kredietroebel had eene goud-waarde, doch eene volkomen onzekere en alleen omdat ziju waarde beheerscht werd door de betalingsverhoudingen met het buitenland en daar het goud waardemeter was. "Maar met den goudroebel - schrijft Von SchulzeGävernitz - had de kredietroebel absolunt niets te makeu, daar beide slechts via den zilverroebel en dit alleen door den geldkoers van den goudroebel op groud eener volkomen verouderde waardeverhouding verbouden wareu."

De schrijver merkt daarbij nog op dat, daar de goudwaarde van den roebel aldus uitsluitend beheerscht werd door de wisselkoersen op Londen en Berlijn en hieruit voor de jaren 1884 tot 1895 een gemiddelde koers van Mk 2,16 voor deu roebel voortsproot, te recht een hiermede overeenkomende waarde voor den nieuwen gondroebel is aangenomen. 1)

1) Von Schulze-Gävernitz bl. 474/5. 
Zeer belangrijk zijn verder de beschouwingen van dezen schrijver ten aanzien van de juistheid van het beleid der Russische regeering in de vaststelling der goudwaarde van den roebel op den gevolgden weg, in plaats van dat door haar tot opdrijving van den kredietroebel tot hoogere goudwaarde werd overgegaan; alsmede zijne niteenzetting, dat door aldus : te handelen de regeering ook inderdaad de verschillende bij de muntregeling betrokken belangen volkomen geëerbiedigd en de onderscheidene belanghebbenden voor verliezen gevrijwaard heeft.

Opmerkelijk is het trouwens dat tegenover de oppositie der muntregeling die, als gezegd, voornamelijk in Rusland zelf gevoerd werd en waarbij dikwijls het niet moeilijk viel te ontdekken dat belangeloosheid er niet bij voorzat, in het algemeen in het buitenland bij de beste autoriteiten in muntzaken die oppositje volstrekt geen weerklank, integendeel slechts veroordeeling vond. Noemen wij ten bewijze hiervan nog slechts prof. Juexis. In zijn geschrift over "Die Wiederherstellung der Valuta in Russland" ") verdedigt hij uitdrukkelijk het goed recht der regeering, ow voor den kredietroebel eene goudwaarde aan te nemen afwijkende van die der oude goudroebels. Nooit, zegt hij en toont hij uit de officieele stukken aan, was aan deze anders dan eene handelswaarde toegekend, terwijl tot aan de munthervorming de zilveren roebel alleen munteenheid was geweest. ${ }^{2}$ )

Het komt ook ons voor, dat de Russische regeering bij hare jongste munthervorming volkomen naar recht en billijkheid gehandeld heeft.

De keuze van de muntstandaard is regeeringszaak. Het moet een onderwerp uitmaken van de staatszorg, te waken dat het wettig betaalmiddel de meest mogelijke wardevastheid hebbe.

1) Hand worterbuch der Staatswissenschaften. Zweiter Supplementband. 1897.

2) Ook Haupt schreef in zijn in 1886 uitgegeven "L'Histoire monétaire de notre temps» bij zijne beschrijving van de destijds bestaande muntregeling van Rusland als volgt: "Nous venons de faire allusion à la valeur intrinsèque du rouble métallique, que nous avons fixée à 4 francs. Il convient néanmoins de rappeler que la base d'origine du sijstème monétaire russe n'était pas l'or, mais l'argent. 
Hieruit vloeit voort, dat wijziging van inuntstandaard noodzakelijk geacht kan worden. Trouweus, althans in Nederland behoeft de juistheid van dit beginsel wel niet verdedigd te worden. Maar eenmaal de muntstandaard vastgesteld zijnde en zoolang als daarin niet op wettige wijze verandering is gebracht, inoet er voor gewaakt worden dat ook werkelijk de waarde van het betaalmiddel volkomen en uitsluitend af hankelijk $z i j$ van die van het metaal dat gekozen is tot muntstandaard. En wordt besloten tot overgang vau het eene metaal op het andere als muntstandaard, omdat dit wenschelijk wordt geacht ter betere verzekering van de waardevastheid van het betaalmiddel, dan moet bij den overgang gewaakt worden tegen wijziging daardoor van de waarde die het betaalmiddel op dat oogenblik heeft. Aldus is ook ten onzent gehandeld bij den overgang vau den zilveren tot den gouden standaard. De waardeverhouding van de nieuwe gouden standaardmunt tegenover de vroegere zilveren staudaardmunt is toen bepaald op 0,604.8 gram fijn goud gelijk aan 9,4.j gram fijn zilver. En van dit oogenblik af heeft op den Staat de plicht gerust er voor te waken, dat de Nederlaudsche gulden steeds de waarde zal houden van 0,6048 grain fijn goud. Dat tevens besloten werd de oude zilveren inuntspecien als teekenmunt in de circulatie te laten, makt hierin geen verandering. Als standaardmunt had het zilver afgedaan en moest voortaan alleen het goud dienst doen. Zou ooit, wat thans wel niet denkbaar is, weder tot het zilver als standaardmunt terug yekomen worden, dan zou alsdau een nieuwe zilveren gulden de munteenheid moeten worlen en dat wel eeu zilveren gulden, warvan op dat oogenblik de inetaalwaarde overeen zou moeten kowen inet $0,604.8$ gram fijn goud.

Letten wij nu op hetgeen in het wezen der zaak in Rusland is voorgevalleu. Ook daar is meu overgeganu van den zilveren op den gouden standaard. Doch het is in Rusland geweest een overgang in twee bedrijuen, in twee tempo's.

Rusland had den zilveren standaard. Naast het zilveren muutstuk stond echter staatspapierengeld als vertegenwoordiger daarvan. Doch onder den drang der omstandigheden kwam men tot overmatige uitgifte van het fiduciaire betaalmiddel en het gevolg was, dit atn de inwisselbaarheid daarvan de haud njet gehouden koll worden en het kredietpapier tegenover de stan- 
daardmunt gedeprecieerd werd. Onbetwijfelbaar is de toenmalige regeering, dien loop van zaken niet voorkomende, tekort geschoten in hare verplichting om te zorgen voor de waardevastheid van het betaalmiddel. Maar daarna is er, terwijl de regeering bedacht was op de middelen ter terugkeer tot de speciebetalingen, eeu oogenblik gekomen waarop door haar voorzien werd, dat het zilver in zijn verhouding tot alle andere koopwaren en in de eerste plaats tot het goud nog meer gedeprecieerd zou worden dan het fiduciaire betaalmiddel in Rusland. Werd nu de band tusschen den kredietroebel en het zilver niet verbroken, dan zou dit den kredietroebel in zijn val medegesleept en aldus een nieuwe waardevermindering van het betaalmiddel veroorzaakt hebben. Om dit te voorkomen werd nu aanstonds de vrije zilveraanmunting geschorst en daardoor feitelijk aan het blanke metaal zijue hoedanigheid van standaardmunt ontnomen. Doch de gouden standaard kon nog niet worden aangenomen, omdat de Staat nog niet-over de middelen beschikte ter hervatting der speciebetalingen. Van eene dadelijke vaststelling der waardeverhouding tusschen de beide metalen vnor den overgang van standaard kon dientengevolge nog geen sprake zijn. De beslissing hieromtrent moest tot later uitgesteld worden en zou dan afhankelijk wezen van de werkelijke alsdan bestaande waardeverhouding van den kredietroebel tot het goud. En zoo is inderdaad geschied. Incorrect in deze was alleen de vroegere handelwijze der regeering, toen zij door hare papier-uitgiften de depreciatie van het betalmiddel veroorzaakte. In hare verdere handelingen in de materie heeft zij daarentegen op de bestmogelijke wijze gewaakt tegen kunstmatige verstoring der waardevastheid daarvan.

Komen wij thans tot het tweede punt: de waarborg voor de duurzaamheid der speciebetalingen welke in de muntregeling gevonden wordt.

Eén feit dient hier voorop gesteld te worden. Te weten dat niet alleen, gelijk hierboven reeds gezegd is, het in werking treden van de munthervorming eerst heeft plaats gevonden toen proefondervindelijk gebleken was, dat bij de daartoe aangenomen goud-pariteit van den kredietroebel de betalingsbalaus zich voor Rusland gunstig stelde, maar dat de regeering begonnen was 
een goudvoorraad op te zamelen zó anzieulijk, dat alle uitgegeven kredietbilletten tot op den laatsten roebel toe onmiddellijk tegen goud ingewisseld hadden kunnen worden.

Daarbij was die goudvoorraad verkregen door de meest treffende verandering welke ooit of ergens in korten tijd in het beheer van staatsfinancien waar te nemen is geweest. De papier-uitgiften hadden hun oorsprong gevonden in het vroeger schier chronisch deficit van het budget. Die oorzaak, meende te recht de regeering, moest verdwijnen zou het kwaad verholpen kunnen worden. Om dit doel te bereiken is men toen overgegaan tot een aantal hervormingen betreffende het belastingstelsel, het stelsel van spoorwegaanleg en exploitatie, het algemeen financieel beheer en de staatsschuld; hervormingen trouwens in nauw verband staande met den nieuwen koers, die in geheel de economische politiek der regeering werd gevolgd.

De uitkomst is voor de jaren 1887 tot 1898 ten aanzien van het budget der gewone uitgaven en ontrangsten geweest als volgt: 1)

In millioentallen kredietroebels.

$\begin{array}{ccccc}1887 & \text { Ontrangsten. } & \text { Uitgaven. } & \text { Overschot. } & \text { Deficit. } \\ 21^{6} & 820^{3} & 841^{9} & & \\ 1888 & 873^{5} & 836^{9} & 36^{6} & \\ 1889 & 914^{5} & 868^{8} & 45^{7} & \\ 1890 & 933^{3} & 914^{7} & 18^{6} & \\ 1891 & 890^{5} & 925^{3} & & 34^{8} \\ 1892 & 964^{6} & 952^{5} & 12^{1} & \\ 1893 & 1031^{4} & 996^{3} & 35^{1} & \\ 1894 & 1145^{3} & 1045^{5} & 99^{8} & \\ 1895 & 1244^{3} & 1129^{4} & 114^{9} & \\ 1896 & 1368^{7} & 1229^{0} & 139^{7} & \\ 1897 & 1416^{3} & 1298^{9} & 117^{4} & \\ 1898 & 1584^{8} & 1358^{2} & 226^{6} & \end{array}$

Sedert 1888 dus, behalve in 1891 dat een jaar van misoogst was, aanhoudend batige saldo's, die vooral in de laatste jaren zeer aanzienlijk zijn geworden.

De batige saldo's der gewone budgetten zijn ten goede

1) Wij ontleenen de cijfers aan het Bulletin Russe de Statistique financière et de Législation $n^{\circ} 7 / 91899$ bl. 471 v. 
gekomen aan die van de buitengewone uitgaven en ontrangsteu. Hoofd-element in deze waren de overnamen van particuliere spoorwegen en aauleg van staatsspoorwegen en de hiermede en met de conversien der staatsschuld in verband staande kredietoperatien. Voorts heeft ten laste van het gezamenlijke budget, tot op het einde van 1896 , gevormd kunnen worden een fonds tot dekking der kredietbilletten, dat geklommen is tot 500 millioen goudroebels $=\mathbf{7 5 0}$ millioen kredietroebels. Met den uit anderen hoofde in de Schatkist en bij de Bank aanwezigen goudvoorraad stond dientengevolge, gelijk hierboven is gezegd, op het eiude van 1896 tegenover een bedrag van 1121 millioen billetten een totaalsom van ruim 1200 millioen kredietroebels in goud.

Teekenen wij hierbij aan dat de staatsschuld die begin 1887 aan nominaal kapitaal bedroeg, herleid in kredietroebels, 5281 millioen, ${ }^{1}$ ) sedert dien aanmerkelijk is gestegen; het totaslbedrag is per 1 Januari 1900 kredietroebels 6150 millioen. ${ }^{2}$ ) Maar daartegenover staat ook, dat van 1 Januari 1887 tot 1 Januari 1899 voor overname en aanbouw van spoorwegen werd uitgegeven 1564 millioeu roebel; voor 1139 millioen werd dit bedrag gedekt uit nieuwe leeningen, voor 4,25 millioen uit de batige saldo's van het gewone budget. ${ }^{3}$ ) En, veel beteekenende bijzonderheid, terwijl in 1887 de dienst der staatsschuld een uitgaaf vorderde van ruim 280 millioen roebels, wordt daarvoor voor 1900 slechts gevorderd $273^{8}$ millioen roebels. Terwijl dus het kapitaal der staatsschuld sedert 1887 met bijkans 900 millioen roebels is vermeerderd, is de daaruit voortspruiteude jaarlijksche uitgave ongeveer gelijk gebleven, zelfs nog iets verminderd. Dit gunstg verschil spruit hiernit voort, dat in $1887 \mathrm{de}$ in het buitenland verschuldigde rente tengevolge van den toenmaligen wisselkoers in roebels zeer nadeelig uitkwam en vooral uit de vermindering van den rentelast door de conversiën; eindelijk, maar dit slechts voor een gering deel, doordat met de conversiën ook gepaard is

1) V̀on Schulze-Gävernitz bl. 556 .

2) Bulletin Russe no 7/9 1899.

3) Von Schulze-Gävernitz bl. 560. A. Raffalovich I. Le Budget Russe de 1899. L'Economiste francais 1899 . I bl. 70 v. 
gegaau eene vermindering der verplichte jaarlijksche amortisatie. ${ }^{1}$ )

Maar keeren wij tot het eigenlijke punt in behandeling terug. Op het oogenblik dat de munthervorming tot uitvoering kwam was, zagen wij, er een goudvoorraad grooter dan de totaalsom der uitstaande billetten. Die billetten zijn echter niet aaustonds voor het geheele bedrag ingetrokken. Wel is dit successievelijk voor een niet onaanzienlijk bedrag geschied. Van ruim 1100 millioen is het bedrag der uitgifte verminderd tot, op I Maart 1.1., 630 millioen, en voor zooveel als de billetten ingewisseld werden door de Bank gouden muntspeciën in den geldomloop gebracht. Naar men meent te mogen aannemen is dit goud ook in de circulatie gebleven; minister de Witte begrootte, luidens zijne nota betreffende den munttoestand $\mathrm{dd}^{\circ} 23$ October 1899, het werkelijk in omloop zijnde goudgeld op ruim 660 millioen roebel. ${ }^{2}$ )

Nog altijd evenwel is een zeker bedrag aan billetten in omloop en is het ook de bedoeling die billetten-circulatie te laten bestaan en dat de Russische Bank daarin een element zal vinden, dat haar behulpzaam moet wezen om de geldcirculatie in het land te regelen en te beheerschen. De kredietbilletten moeten in de geldcirculatie in Rusland de rol vervullen van bankbilletten, de Russische Bank zelve de taak eener circulatiebank.

Minister de Witte heeft dit uitdrukkelijk te kennen gegeven in zijn rapport aan den Keizer ddo 1 Januari 1898. Een goed bankstelsel, schreef hij daar, is een onmisbaar element voor een goed muntwezen. En aan de eischen dienaangaande zou, volgens hem, de Russische Bank voldoen.

Bij haar, zegt hij, concentreeren zich de beschikbare middelen van het geheele land; zij maakt ze weder dienstbaar waar daaraan behoefte bestaat. Zij regelt den discontokoers en in het algemeen den rentestand in het land. Door haar kredietgevingen in te krimpen en bezwaarlijker te maken of wel daarin ruimer te werk te gaan en de voorwaarden gemakkelijker te stellen, kan ze haar invloed doen gevoelen in al de

1) Zie voor de bijzonderheden dienaangaande Von SchulzeGüvernitz blz. 557.

$\left.{ }^{2}\right)$ De Nota is overgenomen in het Bulletin Russe No 7/9 1899. 
vertakkingen van het verkeer; wanneer het noodig is metaaluitvoer tegengann; bij overspanning de nijverheid in hare bewegingen matigen; bij ernstige crises de openbare markt te hulp komen. 1)

Lorini, de vraag behandelende of nu inderdaad de goudcirculatie in Rusland verzekerd is, schijnt ook aan het doeltreffende der thans bestaande regeling van zaken niet te twijfelen. Hij achtte het gevaar voor de wegrloeiing van het goud nit het land na de hervattiug der speciebetalingen deukbeeldig. Een land, zeide hij, heeft altijd het goud dat het noodig heeft; mits slechts men de circulatie vrij late, zal steeds door de internationale handelsbeweging de hoeveelheid van het metaal, vereischt om de prijzen te handhaven in evenwicht met die van het buitenland, behouden worden, of althans, indien tijdelijk overmatige uitvoer zou ziju voorgekomen, het te veel uitgevoerde onmiddellijk terugstroomen. ${ }^{2}$ )

Aldus redeneerende bewoog de schrijver zich echter op het gebied der abstracte theorie en liet hij buiten beschouwing de vraag, of inderdaad de regeling van zaken in Rusland beantwoordt aan de door hem bedoelde eischen.

En welke is nu in deze de werkelijke stelling, welke door de Russische Bank wordt ingenomen?

Wij vinden wat dit betreft in Ruslaud eene regeling van zaken die met geen andere in Europa gelijk staat.

De meeste overeenkomst bestaat nog met Engeland. Evenals de Engelsche Bank gemachtigd is tot het uitgeven van ongedekte billetten tot een bepaald maximum, terwijl voor ieder bedrag daarboven volledige dekking wordt vereiseht, is aan de Russische Bank de verplichting opgelegd van volledige dekking voor zooveel de uitgegeven billetten een bedrag van 600 millioen roebel overschrijden en tot op dit bedrag voor de helft, zijnde dus voor de ongedekte billetten een maximum van 300 millioen gesteld. Maar hiermede houdt ook de overeenkomst op. De verdeeling der Engelsche Bank in "Issue-Department" en "BankingDepartment" mist men bij de tegenwoordige inrichting van de

1) Men vindt de voornaamste inhoud van dit rapport o. a. bij Ledos de Beaufort. bl. 6/21.

2) Lorini. Hdst. VI $\$ 35$.

Econ. 1900. 
Russische Bank. En dit verschil is niet louter formeel; de Engelsche Bank is wat betreft de bank-afdeeling eene van den Staat volkomen onafhankelijke instelling, de Russische Bank is in den volsten zin en geheel en al staatsbank. Ze is dit doordat haar stamkapitaal door den staat is gefonrneerd, door de samenstelling van haar bestuur, en doordat haar beleid van zaken ook geheel beheerscht wordt door de financieele en economische politiek der regeering; en eindelijk nog in zooverre als ze slechts voor eeu deel de vlottende middelen waarmede zij aan de kredietaanvragen moet voldoen aan het publiek ontleent, voor een ander en zelfs voor het grooter deel dit ook weder doet aan den staat.

Bovendien moet hier niet over het hoofd worden gezien, dat de Engelsche Bank de centrale bankinstelling is in een land waar het bankwezen zeer krachtig en doeltreffend georganiseerd is en diep ingrijpt in het algemeen verkeer; in een land daarbij, waar men in alle oorden van de wereld onder allerlei vormen hoogst belangrijke vorderingen heeft uitstaan, waardoor steeds in zeer korten tijd de beschikking herkregen kan worden over aanzienlijke kapitalen. En het is er verre van daan, dat de algemeene toestand in deze in Rusland en die van de Russische Bank in het bijzonder, met dien van Engeland en van de Engelsohe Bank overeenkomen.

Zoo bekleeden dan ook inderdaad onder de operatien van de Russische Bank de gemakkelijk en schielijk weder los te maken plaatsingen eene betrekkelijk slechts geringe plaats. Men vindt in het werk van Von Schulze-Gävernitz ${ }^{1}$ ) eene zeer nitvoerige behandeling van den bank-staat met betrekking tot dit punt. De schrijver doet daarbij intusschen opmerken, dat in vergelijking met vroegere toestanden de tegenwoordige reeds eene aanmerkelijke verbetering aantoont, de gebreken in sommige gevallen eigenlijk reeds niet meer dan "schoonheidsvlekjes" zijn. Maar toch is zijne conclusie, dat er naar gestreefd moet worden de kredietbilletten door invoering van werkelijk bankmässiger dekking tot ware bankbilletten te maken, en eerst dan de goudeirculatie een voldongen en onaantastbaar feit zal zijn. Dit doel acht hij echter eerst langzamerhand bereikbaar

1) Bfdst. VI. 1. B. 
te zijn en slechts in verband met de algemeene economische ontwikkeling van het land.

Mijns inziens is het daarbij bepaald een zwak punt dat de Bank voor een belangrijk deel haar vlottende middelen ontleent aan het groote credit-saldo van de schatkist, en daardoor niet, of althans niet uitsluitend is, zooals minister de Witte in genoemd rapport schreef, de verzamelaarster van de beschikbare middelen van het land om daarmede aan de krediet-aanvragen van andere zijden te voldoen. Zoo vindt men in den jongst gepubliceerden bankstaat, dien van 1/14 Maart ll. tegenover een totaalsom (in ronde cijfers) van 329.770 .000 roebel discontos en voorschotten op fondsen en goederen, aan deposito's op zicht en op diverse termijnen en rekening-courant saldo's van particulieren, krediet- en handels-instellingen slechts een totaal bedrag van 149.172.000 roebel, maar daarnaast, behalve consignatiegelden 144.539.000 roebel en rekening-courant saldo's van diverse publieke instellingen 38.631 .000 roebel, rekeningcourant saldo van de schatkist 440.517 .000 roebel. Onwillekeurig dringt zich de vraag op: hoe zou, bij eene dergelijke verhouding in de vlottende middelen der bank, de toestand worden indien eens moeilijke dagen aanbraken en de schatkist over haar saldo zou moeten beschikken?

Haasten wij ons echter hier onmiddellijk aan toe te voegen, dat, hoezeer er ook in het abstracte voor dergelijke opmerking aanleiding bestaat, in de werkelijkheid er voor bezorgdheid geen reden hoegenaamd bestaat.

Ten eerste worde niet vergeten, dat in de verhouding van de Bank tot den Staat door de Ukase van 29 Augustus 1897 eene hoogst belangrijke principieele verbetering is gebracht. Immers werd, zooals hierboven is vermeld, daarbij voorgeschreven dat de billetten voortaan en steeds met inachtneming van de bepalingen betreffende de verplichte gouddekking, uitsluitend worden uitgegeven ter voldoening aan de behoeften der geldmarkt; dns niet meer ter verschaffing van geldmiddelen aan de schatkist.

Ten tweede, wat bepaaldelijk het rekening courant saldo van de schatkist betreft, moet in acht genomen worden, dat bij de tegenwoordige methode in het beheer der financien er altijd een zeer aanzienlijk saldo aanwezig moet blijven. Iv de voorrede 
van het onlangs voor het eerst versehenen "The Russian Jourual of Financial Statistics" heeft de bekwame redacteur van het Bulletin Russe, de heer Barbet de Vaux, ter voorlichting van het Engelsche publiek en ter bestrijding van de min of meer vijandige beschouwingen over de financiën van Rusland, die unen zoo menigmaal zelfs in goed aangeschreven Engelsche bladen vindt, zeer belangrijke ophelderingen en mededeelingen gegeven over die fuanciën. 1) Weluu, daaruit blijkt dat nooit kredieten worden geopend op het buitengewone Budget wanneer niet bereids de middelen aanwezig ziju, en de voor die kredieten benoodigde sommen alsdan dadelijk van het beschikbaar saldo der schatkist worden afgeschreven, al zijn er soms ook jaren mêe gemoeid dat over het krediet geheel beschikt kan worden. Van daar aanhoudend een zeer groot kas-saldo bij de schatkist. De cijfers - ontleend aan het jaarverslag van de Russische rekenkamer - ziju te belangrijk dan dat wij ze hier onvermeld mogen laten:

In millioentalleu roebels.

Totaal kas- Waarv. vrij-saldo, zegge Verschil, zijnde kas-saldo saldo v. d. kas-saldo waartegen nog strekkende ter voldoen.

1 Januari. schatkist. geen krediet geopend. van geopende kredieten.

$\begin{array}{llrl}1889 & 311^{4} & 141^{2} & 170^{2} \\ 1890 & 379^{8} & 192^{5} & 187^{1} \\ 1891 & 44^{8} & 204^{9} & 261^{9} \\ 1892 & 319^{1} & 25^{4} & 293^{7} \\ 1893 & 346^{2} & 71^{9} & 274^{2} \\ 1894 & 544^{8} & 239^{5} & 305^{2} \\ 1895 & 732^{3} & 333^{4} & 398^{\circ} \\ 1896 & 628^{8} & 273^{9} & 354^{9} \\ 1897 & 755^{8} & 246^{4} & 509^{3} \\ 1898 & 562^{5} & 214^{7} & 347^{9} \\ 1899 & 545^{6} & 134^{8} & 410^{7}\end{array}$

En eindelijk is er de zeer ruime gouddekking der billetten. Volgens den bankstaat van 1/14 Maart 1.l. was op dien datum de toestand de volgende:

1) The Russian Journal of Financial Statistics, St. Petersburg, 1899. Aldaar «By way of preface». Een fransche vertaling is opgenomen in het Bulletin Russe $n^{\circ} 7 / 91899$. 
Totaal bedrag der kredietbilletten . . . Rb. 630.000 .000 waarvan in kas bij de bank zelve - in

ronde som - . . . . . . . . . . " 125.966 .000

dus billetten in circulatie . . . . . . Rb. 504.084.000

maakt verplichte goud-dekking. . . . . Bb. 252.017.000 daarentegen voorraad gouden munt en muntmateriaal . . . . . . . . . . . . " 828.680 .000 zegge surplus-dekking. . . . . . . . Rb. 576.663.000

Fin daar nu op dien datum het rekening-courant saldo der schatkist ruim 440 millioen roebel bedroeg, blijkt het dat de bank dit saldo toen ten volle in goud had kunuen rembourseeren en dan nog een surplus-dekking van 136 millioen roebels had overgehouden. Dit ciffer is van te meer beteekenis omdat de bank in de laatste maanden aan hare kredietoperatiën een niet onbelangrijke uitbreiding had gegeven; tegenover het daar straks genoemde cijfer van 329 millioen aan disconto's en beleeningen op 1 Maart 1.l. stond op 1 April 1899 slechts een bedrag van 221 millioen.

Ten slotte dient ten opzichte van het thans behandelde punt ook nog het volgende opgemerkt te worden.

Zeer zeker is, zooals wij zeiden, het er verre van daan dat in Rusland een algemeene bank-organisatie gevonden wordt welke overeenkomt met die in Engeland. Dit neemt echter niet weg dat ook wat dit betreft er in den lateren tijd aanzienlijke vooruitgang valt waar te nemen.

Vóór 1861, het jaar van de vrijmaking der lijfeigenen, mas schrijft L. Raffalovich ') - het bankbedrijf in Kusland schier onbekend, maar sedert heeft het groote ontwikkeling ondervouden. Men telde laatstelijk, op 1 Januari 1898, deelt hij mede:

a) 209 Stedelijke openbare bauken met een gezamenlijk, kapitaal vau $\mathrm{Rb}$. 31.050 .000 en een totaal balans-cijfer van Rb. 133.737.000. Dit ziju echter slechts kleine instellingen doch met een uitgebreid veld van werkzaamheid en die juist daardoor plaatselijk groote diensten bewijzen.

b.) 99 Onderlinge kredietvereenigingen met gezamenlijk

1) L. Raffalovich «Banking in Russia.* Lezing gehouden te Londen in The Institute of Bankers op 12 April 1899. 
66.954 leden en een totaal balans-cijfer van Rb. 215.409.000. Deze vereenigingen zijn vooral in de steden van eenige beteekenis gevestigd.

En eindelijk c) en hier komt het vooral opaan,

37 handelsbanken met gezamenlijk 233 agentschappen en bijkantoren. Deze bankeu mogen zich uitsluitend met operatiën op korten termijn bezighouden. Alle banken in Rusland staan onder stantscontrole, zij moeten b. v. maandelijks een situatie-staat bekend maken en aan de regeering inzenden. Op 1 Januari 1897 waren de gezamenlijke eijfers der loofd-rekeningen dezer 37 banken als volgt:

in duizendtallen roebels.

Actief.

Cassa . . . . . . . . . . . 30.959

A deposito nitgezet . . . . . . 23.611

Disconto's. . . . . . . . . . 246.887

Voorschotten. . . . . . . . . 313.192

Passief.

Kapitaal . . . . . . . . . . 164.082

Reservefonds . . . . . . . . . 68.713

Deposito's. . . . . . . . . . 369.860

Billetten mogen de banken niet uitgeven; dit is het uitsluitend recht van de Staatsbank.

Teekenen wij eindelijk nog éne getuigenis op waaruit, op ongezochte wijze, blijkt hoezeer in handelskringen erkend wordt, dat de Russische Bank thans inderdaad wel degelijk in de positie is gekomen, dat zij door haren discontokoers de wisselkoersen op het buitenland beheerscht. In eene onlangs gehouden lezing over de internationale geldmarkt merkte de heer C. Rozenraad op, dat het nog zou moeten blijken of op den langen duar de Bank haar goudvoorraad tegen uitvoer zou kunnen beschermen, immers - zeide hij - was in het najaar van 1899 de russische wisselkoers op Engeland op het gouduitvoerpunt gekomen en de Bauk had toen haar discontokoers op 7 pCt. moeten brengen om hierin een keer te breugen ').

1) C. Rozenraad. The international money market. Lezing 16 Januari 1900 gehouden in The Royal Statistical Society. Opgenomen in haar Journal. deel $63,1^{\text {ste }}$ afl. 
Maar omstreeks denzelfden tijd heeft ook de Duitsche Rijksbank haren discontokoers op 7 pCt. moeten verhoogen en de Engel sehe Bank zelve op 6 pCt. Tegenover die koersen was 7 pCt. te Petersburg waarlijk niet buitensporig. Had door het middel der discontoverhooging de Russische bank de beweging niet kunnen beheerschen, zoo ware dat een ongunstig verschijusel geweest. $\mathrm{Nu}$ heeft zij integendeel bewezen dat, de discontopolitiek der voornaamste Europeesche banken te volgen, ook voor haar een afdoend verdedigingsmiddel is.

Er is én zaak waarop bij de beoordeeling der russische toestanden steeds gelet moet worden en die inzonderheid in verband met de valuta-kwestie van groote beteekenis is. ' $t$ Is het feit dat een belangrijk deel der staatssehuld in het buitenland is geplaatst.

De aanzienlijke en gemakkelijke opname van russische fondsen in Frankrijk in de laatste jaren heeft, welke ook de voordeelen daarvan voor Rusland zijn geweest, het aan dergelijken stand van zaken verbonden bezwaar toch noodwendig vermeerderd.

Dit bewaar bestaat, ten eenre, in hel gevaar dat b. v. onder den invloed van staatkundige verwiktelingen het buitenland zich van die foudsen zou willen ontdoen of althans zijn bezit daarvan zou willen verminderen. Er ontstaat dau van zelf een terugstrooming der staatsschuld nanr het eigen land, hetgeen zooveel beteekent als een plotselinge opvraging van kapitaal door den geldschieter aan den geldopnemer. En nu moge de laatstgenoemde geen verplichting hebben aan die opvraying te voldoen oudat het geen vervallen vordering betreft, er zal in het land zelf altijd een neiging bestann om de koersdaling der staatsschuld, warnede natuuurlijk de beweging gepaard gaat, tegen te houden; hetzij omdat men zelf die daling viet gemotiveerd acht, hetzij omdat men het gewenseht acht op die wijze een poging te doen om de beweging te keer te gaan. Dat, bij de verhouding van het russische ministerie van financien tot de beurs en bij zijn invloed op het beleid van zaken der Bank, bepaaldelijk in Rusland de mogelijkheid zou bestaan dat op een gegeven oogenblik men in die richting werkzaam zou worden, is niet twijfelachtig. Te wenschen is bet echter 
zeer zeker dat, eventueel, men zich van iedere dergelijke poging zou onthouden. Er zou, ging wen aldus handelen, geen midldel zijn om dit mogelijk te maken dan let bederven van den geldomloop, al ware het allicht aanvankelijk alleen door bet aantasten der metaal-reserve. De ervaring leert dat men zich alsdan begeeft op een hellend vak, waarvan terugkeeren steeds moeilijker en bezwarender wordt naarmate inen er verder op afglijdt. Men zij daaroin in Rusland, zouden, hetzij door politieke verwikkelingen of door algemeene verhooging van den rentestand, de staatsfondsen gaan dalen, er wel op bedacht dergelijke beweging niet door kunstmatige middelen, te ker te willen gaan!

Het bezwaar der buitenlandsche plaatsing van staatsschuld is, ten andere, de invloed welken dit beeft op de betalingsbalans van het land. Naarmate een staat zijn schuld in den vreemde onderbrengt, wordt hij als het ware schatplichtig aan het buitenland.

De beteekenis hiervan verschilt intusschen aanmerkelijk naar gelang van het gebruik dat van de opbrengst der buitenlandsche leeningen is gemaakt. Moest deze dienen om oorlog te voeren, zoo zal tegenover de jaarlijks naar buiten te maken remises geeu vermeerdering der binnenlandsche voortbrenging zijn ontstaan. Dan drukt die buitenlandsche rentelast zeer zwaar op het land en het gevaar is groot, dat alsdan onder ongunstige omstaudigheden het vlottend kapitaal wordt aangesproken om te voorzien in hetgeen uit het volksinkomen, d. i. de jaarlijksche voortbrenging, moeilijk bestreden kan worden; m. a. w. dat aan den geldomloop metaal worde ontnomen en dit daar door papier wordt vervangen. Anders is het echter wanneer de opbrengst der leening gestrekt heeft om op een of andere wijze de voortbrenging des lands te vermeerderen. Dan toch staan tegenover de naar buiten over te maken renten nieuwe voortbreugselen, vermoedelijk van grootere beteekenis dan het rentebedrag, zoodat een deel daarvan kan worden uitgevoerd eu het meerdere zuivere winst voor het land is; of wordt indirekt dezelfde uitkomst verkregen doordat voorwerpen, welke vroeger uit den vreemde moesten worden ingevoerd, voortaan in het land zelf worden voortgebracht. Dit verschil verklaart juist ten opzichte van Rusland, dat hoe aanzienlijk ze ook waren, de 
buitenlandsche leeningen van de latere jaren, leeningen hoofdzakelijk aangegaan ten behoeve van spoorweg-aanleg, geen nadeeligen invloed hebben gebad op den economischen en financieelen toestand van het land, terwijl vroegere leeningen van minder bedrag integendeel grooten druk uitoefenden.

Nochtans ook aan de meest productieve leeningen blijft ten aanzien van den aau het buitenland te kwijten rentelast altijd eenig bezwaar verbonden. Voorzoover toch tegen de jaarlijksche handelsuitvoeren invoeren van andere koopwaren staan, kunuen de invoeren ingekort worden wauneer soms, onder welke omstandigheden ook, de uitvoeren afnemen. Maar de rentelast blijft dezelfde hoe ook de handelsuitvoeren zouden verminderen.

Economische verschijuselen verkrijgen dientengevolge in eeu land als Rusland allicht een grootere beteekenis dan elders. Een goede economische politiek te volgen is inzonderheid daar voor de regeering een dure verplichting.

De groote vraag is nu maar, wat is voor Rusland de meest gewenschte economische politiek?

De heer l,orini besluit zijn boek met een jaumerklacht, dat de vrijhandels-politiek niet in Rusland wordt gevolgd '). $\mathrm{Hij}$ heeft geen woorden genoeg on zich te verbazen dat een man, die zulk een groot voorstander is van de goudbetalingen als minister de Witte, in zijn verslag over de Begrooting van 1897 zich lieeft kunneu verklaren ten guuste vau het behoud der protectionistische politiek welke in de laatste jaren door de 'regeeriug werd gevolgd. De schiminen van Adam Smith, Ricardo en Mill worden opgeroepen om de Witte te verpletteren.

Wij kunnen in die verontwaardiging niet deelen. Lorini toont zich hier eeu doctrinair bij uitnemendheid en daarbij een aanhauger van de Manchester-school zooals er slechts weinige meer gevonden worden. Hij heeft geen oog voor het groote verschil van omstandigheden tusschen het Rusland van het tegenwoordige oogenblik en een land als Engelaud of kunnen wij bijvoegen - als Nederland.

Veel lager bij den grond dan hijzelf, winder de zaken dezer aarde met Olympische grootheid slechts van het standpunt van

1) Lorini. Hfdst. VI $\S 36$, v. 
"de school" beziende, staat zeker in de oogen van Lorini een mau als Von Schulze-Gävernitz. Ook deze is geen echte protectionist, maar hij volgt een geheel andere methode dan Lorini. Door hem wordt de handelswetgeving van Rusland in de $19^{\text {ae }}$ eeuw in bijzonderheden nagegaan. En nu vindt hij daarbij ook wel aanleiding tot kritiek, maar moet hij herhaaldelijk wijzen op het vut dat beschermende rechten voor het ontstaan en de ontwikkeling der Russische nijverheid hebben gehad, an het licht brengen hoe onder de bestaande omstandigheden tot dat hulpmiddel de toevlucht genomen moest worden. 1) Zijn oordeel laat zich resumeeren in de volgende uitspraak: "Laten wij Duitschers ten opzichte van Rusland's industrieele ontwikkeling van den tegenwoordigen tijd ons wachten voor de fout die Friedrich List eens aan de Engelschen verweet, dat zij alléén zich tot industrieele ontwikkeling geroepen achten. Laat ons veelmeer erkennen, dat Rusland op zijn standpunt met recht er naar streeft de groot-iudustrie in eigen land te doeu leven, en ter bereiking van dat doel beschermende rechten moet dienstig maken. Wij kunnen dan echter ook met een gerust geweten daarann toevoegen, dat beschermende rechten niet tot die dingen behooren waarvan het geldt: hoe meer hoe beter." 2)

Men moet er zich wel rekenschap vau geven dat men ten aanzien van het huidige Rusland inderdaad met een gansch eigenaardigen stand van zaken te doen heeft.

Rusland, voor het grooter deel althans, stond een halve eeuw geleden economisch nog schier op het standpunt waaraan de West-Europeesche landen reeds na de middeleeuwen ontwassen zijn. Tot op de vrijmaking der boeren in 1861 heerschte op het platte land nog de toestand die door Dr. Karl Bücher gekenschetst is als het tijdvak der gesloten familiehuishouding. ${ }^{3}$ ) Wel niet die toestand zooals hij in de $6^{\text {de }}$ en $7^{\text {de }}$ eeuw in de

1) Zie bij Von Schnlze Gävernitz. Hfdst. IV. «Die Handelspolitik der achtziger Jahres en in Hfds.. VI afd. IV, Russland's Zahlungsbilanz.»

2) Von Schulze-Gävernitz t. a. p. bl. 267.

3) Dr. Karl Bücher. Die Entstehung der Volkswirtschaft. Tübingen 1893. De eerste voordracht in het boek. 
germaansche landen bestond, maar zooals die daar geworden was toen in de $9^{\text {de }}$ en $10^{\text {de }}$ eeuw het groot grondbezit was ontstaan met de heerlijke vroonhoeven als centra van het landbouwbedrijf. ') Het eigenaardige van deze huishouding, van dezen economischen toestand was, zooals Karl Bücher het uitdrukt, dat er geen prijzen, geen arbeidsloonen, geen pachten of huren, geen kapitaalwinst en dan ook geen ondernemers en loonarbeiders bestonden. In én woord, het $r u i l v e r k e e r$ met zijn commercieele handelingen dat de economische grondslag vormt onzer moderne rnaatschappij ${ }^{2}$ ) ontbrak aan dien toestand nog geheel. Grootendeels althans. En voorzooveel langzamerhand de bevolking aan eenigen handel ging deelnemen, daar gesehiedde het toch nog alleen door de jaarmarkten, overgang van de gesloten familiehuishouding tot onze westerscheuropeesehe op den ruilhandel gegrondveste maatschappij. ${ }^{3}$ )

Rusland verkeert thans, sedert het midden dezer eeuw en bepaaldelijk sedert de eerste zestiger jaren, in die phase van economische ontwikkeling, welke Engeland reeds heeft doorgemaakt van de $13^{\text {de }}$ tot de $17^{\text {de }}$ eeuw, inzonderheid in de tweede helft der $16^{\text {de }}$, Frankrijk eerst in de $17^{\text {de }}$ eeuw , bepaaldelijk onder Colbert, en waarvan de leidende begiuselen in de $19^{\text {de }}$ eeuw ook nog vernieuwde toepassing hebben gevonden in het Duitsche rijk.

1) Men zie ten aanzien dezer toestanden, behalre Dr. Karl Bücher, o. m. Prof. G. Schmoller's «Das Merkantilsystem in seiner historischen Bedeutung: stadtische, territoriale und staatliche Wirtschaftspolitik in Umrisse und Untersuchungen zur Verfassings-, Verwaltungs-, und Wirtschaftsgeschichte» Leipzig 1898. Ook Prof. Mr. M. W. P. Treub. «Een drietal hoofdstukken uit de geschiedenis der stanthuishoudkunde. Haarlem, 1899. Voorts en inzonderheid met het oog op Rusland, bij Von Schulze-Gävernitz het eerste hoofdstuk «Der ältere Merkantilismus.» Eigenaardig is wat deze schrijver mededeelt in zijn tweede hoofdstuk, handelende over de midden-russische katoenindustrie, $t$. $w$. dat zelfs in Moscow in het begin dezer eeuw door Haxthausen nog gevonden werd het sheerenof vroonhuis» in welks neven-gebouwen een duizendtal hoorige bedienden leefden, zonder dat er bij hen wan eenige loonsbetaling sprake was; heer en dienaren leefden te zamen van de opbrengst der door de lijfeigenen-boeren bebouwde gronden.

$\left.{ }^{2}\right)$ Verg. Mr. N. G. Pierson. Leerboek der staatshuishoudkunde. Inleiding.

3) Verg. bij Von Schulze-Gävernitz «Nischninowgorod bl. $60 \mathrm{v}$. 
Het mercantilisme - door de Engelsche economisten van de eerste helft dezer eeuw zoo slecht begrepen en eerst door die der Duitsche school en de jongere economisten in Engeland in zijn ware beteekenis aan het licht gesteld - is het economisehe stelsel waardoor op zijn beurt thans Rusland wordt hervormd.

Het is intusschen onze bedoeling niet hier in algemeene economische beschouwingen te treden. Wij hebben alleen bedoeld een vingerwijzing te doen naar het standpunt waarop men zich heeft te plaatsen om de legenwoordige Russische toestanden te beoordeelen. Keeren wij dan zonder verdere uitweiding tot ons onderwerp terug.

"Door het mercantile stelsel werd beoogd de vorming van een industrieelen en handelsstaat waarin, door beperking der vrijheid of bescherming, door het Staatsgezag particuliere of klassenbelangen dienstig worden gemaakt aan de bevordering der nationale kracht en onaf haukelijkheid." ')

Houdt men dit in het oog dan zal men gereedelijk moeten toegeven, dat nooit voor het tuepassen van het stelsel er zooveel aanleiding bestond als in het Rusland vau het midden dezer eeuw. Ten eenre, eene achterlijke eu armoedige bevolking voor welke, ook wanneer het lijfeigenschap zou opgeheven zijn, de gelegenheid om door verschillenden arbeid haar lot te verbeteren en zich omhoog te werken zeer schaarsch was. Ten andere, rijke natuurlijke hulpbronuen voor eene krachtige en bloeiende nijverheid, doeh deze sehier geheel onontgonnen. Voor alles, behalve voor zijn voedingsıiddelen en de eenvoudigste kleeding, het land afhankelijk van het buiteuland en, ter verkrijging van de buiteulandsche voortbrengselen, slechts kuuuende beschikken over die van deu met gebrekkige mildeleu gedreven landbouw. Zijn handelsbalans dientengevolge ook geheel afhaukelijk van de uitkomsten van den jaarlijkschen oogst en deze bij de bestaande landbouw-toestauden altijd onzeker. Zoo was de stand van zaken.

In de eerste plaats moest nu gezorgd worden voor den aanley van spoorwegen die, met uitzondering van zeer enkele lijuen,

1) W. A. S. Hewins. «Mercantile sijstem» in Palgrave's Dictionary of Political Economy. 
tot op het einde der vijftiger jaren geheel ontbraken. Tegelijk echter moest verkregen worden, dat de grondstoffen voor dien aanleg niet uit den preemde ontboden behoefden te worden maar aan den eigen bodem van het land werden ontleend. Ruslands rijkdom toch aan ijzer en kolen of waar deze ontbraken aan hout als brandstof en, gelijk eerlang zou blijken, ook aan nafta was buitengewoou groot. Alle elementen waren dus aanwijzig voor een mineralogische en metalurgische nijverheid zoo bloeiend als waar ook; het kwan er echter slechts opaan die tot ontwikkeling te brengen. Daarbij, niet alleen voor den eigen spoorwegbouw moesten deze natuurlijke rijkdommen dienstbaar gemaakt worden, maar ook om in het algemeen de groot-industrie in het land te vestigen en het daardoor meer algemeen van den vreemde onafhankelijk te maken en het een plaats voor te bereiden onder de landen met uitgebreiden exporthandel, waartoe de ten oosten en ten zuiden omliggende landen een dankbaar afzet-gebied zouden aanbieden. Tevens moest de katoen-industrie, welke reeds vroeger in het Moscowsche district zekere beteekenis had verkregen, tot nieuwe ontwikkeling worden gebracht. En ook de landbouw moest op nieuwe banen worden geleid b. v. door de beetwortelteelt.

Was het dan wonder dat de regeering tot het protectionisme ziju toevlucht nam om het oude Rusland tot een modernen industrie-staat te hervormen? Groote voordeelen werden daardoor aan enkelen verzekerd, maar daardoor ook - onmisbaar vereischte ow het doel te bereiken - de vreemde kapitalen in ruime mate gelokt. En wie, die het hedendaagsch Rusland vergelijkt met dat van roor vijftig jaren, zal het wraken dat die weg werd ingeslagen?

De Hingelsche schrijver aan wien wij hierboven de omschrijving van, het doel van het mercantilisme ontleenden, schreef nog in zijn schets van de historische ontwikkeling daarvan: "That nations should pass through a mercantilist stage seems inevitable." En inderdaad wanneer men ziet wat de toepassing van het stelsel in Rusland heeft uitgewerkt, is het moeielijk tegen dergelijke uitspraak in verzet te komen. De verklaring moet wel zijn dat, welke nadeelen ook aan het protectionisme verbonden zijn, onder bepaalde omstandigheden de bevordering van enkele bijzondere belangen in een land van zoo over- 
wegende beteekenis kan zijn en indirekt op de algemeene welvaart zoo grooten invloed nitoefent, dat de goede gevolgen de slechte ten eeneninale overtreffen.

Toch heeft ook Rusland zelf het bewijs geleverd van de juistheid van ook deze hierboven van Von Schulze-Gävernitz aangehaalde woorden: "dat beschermende rechten niet tot die dingen behooren warvan het geldt: "hoe meer hoe beter."

Leerrijk bij uitnemendheid is wat dit betreft het overzicht dat deze schrijver zelf geeft van de geschiedenis van het russische tarief sedert het begin der $19^{\text {de }}$ eeuw ${ }^{1}$ ), waarbij inzonderheid te letten valt op den gunstigen invloed die in de zestiger en zeventiger jaren ondervonden werd van het destijds betrekkelijk matig tarief. En volgde later weder verscherpte toepassing van het protectionisme, in het allerjongste tijdvak onder minister de Witte is hierop al weder terug gekomen, getuige in de eerste plaats het Duitsch-Russische handelsverdrag van 1894, getuige o. m. ook weder de in 1898 plaatsgevonden belangrijke verlaging der inkomende rechten op landbouw-machineriën en kunstmest.

Minister de Witte is trouwens zeer zeker niet een ultraprotectionist. Dit blijkt reeds nit de woorden met welke hij in zijn rapport aan den Keizer over de Begrooting van 1898 te kennen gaf, dat, eenmaal de weg van het protectionisme gevolgd zijnde, daarvan niet rauwelijk afgeweken kon worden met het oog op de onderuemingen onder dat régime gevestigd, tegenover welke het een groot onrecht zou zijn, terwijl bovendien de in die onderneming alsdan te ondervinden nadeelen zich in breeden kring en veelzijdig zouden doen gevoelen. Geen principieel pleidooi alzoo voor het protectionisme, maar verdediging van volharding daarbij op practische en opportunistische gronden.

$\mathrm{Z}_{\mathrm{ij}} \mathrm{n}$ gansche gedachte over het protectionisme heeft de minister uitgesproken in een redevoering in 1898 gehouden in een landbouwcommissie.

Het protectionistische stelsel - zeide hij daar - heeft tot einddoel de nationale voortbrenging te bevrijden van hare afhankelijkheid van vreemden arbeid en vreemde markten, om het land op te heffen tot eene belangrijke economische eenheir.

1) จ. Schulze-Gävernitz Hfds. IV. 
Zooals alles wat slechts dienst moet doen als middel en niet zijn doel vindt in zichzelf, moet echter het protectionisme geen andere beteekenis hebben dan die van een tijdelijken maatregel, bestemd om slechts zoolang te duren totdat het dnarmede beoogde doel bereikt zal zijn. ')

Men ziet het, de Witte's standpunt is geheel dat der mercantilisten; niets minder, maar ook niets meer. En telkens weer bleek het bij de niteenzetting zijner deukbeelden, hoe hij van de nadeelen van het protectionisme volkomen doordrongen was en daarin alleen zag een noodzakelijk kwaad om tot het eigenlijke doel te komen.

Eéne periode dier redevoering moet hier nog vermeld. Uitdrukkelijk gaf hij te kennen, dat men echter niet moest meenen uitsluitend door het protectionisme de ontwikkeling der nationale voortbrenging te kunnen bevorderen; dat integendeel dartoe voor alles ook moesten dienen verbetering en ruimere verspreiding van het onderwijs, inzonderheid ook van het technisch onderwijs, en verbetering der arbeids-toestanden. Dit is - voegde hij er aan toe - ook het ernstig streven der regeering.

Minister de Witte koint inderdaad, naarmate mei hem in ziju gesehreven stukken en zijne handelingen bestudeert, telkens meer voor als de echte mercantilist, en onwillekeurig komt in de gedachte het beeld dat Karl Bücher schetste van Colbert als de meest typische vertegenwoordiger van het stelsel. Men zou de Witte den Russischen Colbert kunnen noemen. ${ }^{2}$ )

Ten slotte zij hier een plaats gegeven aan eenige statistieke opgaven Daarmee wordt echter uiet bedoeld een volledig overzicht te leveren van de economische ontwikkeling van Rusland. Slechts enkele cijfers kunnen hier vermeld worden om daarvan een denkbeeld te geven.

De eigenlijke aanleg van het Russische spoorwegnet is aangevangen met de concessie in 1857 aan de Groote Maatschappij van Russische spoorwegen gegeven voor 4000 Werst (1 Werst $=1,07 \mathrm{~km}$ ). Te voren bestonden behalve de reeds in 1838 gebouwden spoorweg St. Petersburg-Pawlosk nog slechts twee

1) Men vindt den voornaamsten inhoud van deze redevoering bij A. Raffalovich. Le Marché financier en 1898/99. Hfdst. Russie.

2) Verg. Karl Bücher. Die entstehung der Volkswirtschaft bl. 70 . 
lijnen: Warschaw Weenen en de Nikolai-spoorweg. In 1857 begou de aanleg door concessioneering aan particuliere maatschappijen met stantsgarantie voor de rente en staats-voorschotten. Dit stelsel werd volgehouden tot het begin der tachtiger jaren toen, tengevolge der nadeelige financieele gevolgeu die het voor de schatkist had gegeven, daarmee gebroken werd en weder tot staatsaanleg en staatsexploitatie werd besloten, terwijl eerlang ook werd overgegaan tot naasting van een aantal der particuliere lijnen en de overige onder strenge staats-controle werden geplaatst. Van 1889 tot 1897 volgden verder belangrijke herzieningen van de personen- en goederen tarieven, welke op het verkeer en op de financieele resultaten zeer gunstigen invloed hadden.

De lengte van het spoorwegnet in exploitatie was: ') in het geheel warvan staatsspoorwegen. Kilometers

$\begin{array}{rrrrrrr}\text { in } 1875 & \text {. } & \text {. } & \text {. } & 19.947 & 903 \\ " \prime & 1880 & . & . & . & 22.434 & 2260 \\ " \prime & 1889 & \text {. } & \text {. } & \text {. } & 29.292 & 6902\end{array}$

op 1 Jan. 1900 . . . 45.381

33.693

(hiervan ongeveer $6400 \mathrm{KM}$. in Azië).

Bovendien zullen circa $3200 \mathrm{Km}$. staatslijuen, thans in aaubouw, spoedig in exploitatie komen. De lokaal-spoorwegen zijn in de opgegeven getallen niet begrepen.

Ue ontvangsten op de staatsspoorwegen bedroegen in 1898 . Bruto . . . . . . . . . . . Rb. 327.402 .860 Exploitatiekosten. . . . . . . . " 195.014 .447 Netto . . . . . . . . . . . . Rb. 132.388.413

Van een totaal van $47.742 \mathrm{Km}$. der gezameulijke spoorwegen, staats- en particuliere lijnen, bedroegen in 1898 ,

de bruto-ontvangsten . . . . . . . Rb. 420.873 .000 waarv, uit het goenlerenverv. Rb. 313.867 .000

de exploitatiekosten. . . . . . . . " 244.140.000 netto-ontrangsten . . . . . . . . Rb. 176.733 .000

1) Al de hier gegeven bijzonderheden zijn ontleend aan: Prof Tschuproff. Eisenbahnen in Russland. Conrad's Jahrbücher III Folge d. 18. G. Bourgarel. Les Finances de la Russie, in L'Economiste Européen, 9 Febr. 1900, en aan een officieele opgave medegedeeld in L'Economiste Français 7 April 1900. 
Het aantal vervoerde personen bedroeg:

$$
\begin{aligned}
& \text { in } 1886 \quad 37.885 .000 \\
& \text { " } 1895 \quad 58.620 .000 \\
& \text { " } 189874.383 .000 \\
& \text { het goederen-transport. } \\
& \text { in } 1886 \text { 3.176.689.000 Pud } \\
& \text { " } 18904.179 .412,000 \text { " } \\
& \text { " } 1895 \text { 5.588.537.000 " }
\end{aligned}
$$

( $1 \mathrm{Pud}=16^{38} \mathrm{KG}$.)

alleen op de staatsspoorwegen:

$$
\text { in } 1898 \text { 4.518.727.223 Pud. }
$$

De ten laste van den staat gekomen aanlegkosten bedroegen einde 18963600 millioen roebel

De buitenlandsche handelsbeweging is in de laatste jaren als volgt geweest: ${ }^{1}$ )

\begin{tabular}{cccc}
\multicolumn{3}{c}{ In millioentallen roebels } \\
& \multicolumn{3}{c}{$\begin{array}{c}\text { Meer uitgevoerd } \\
\text { dan ingevoerd }\end{array}$} \\
1885 & 435 & 538 & 103 \\
1886 & 426 & 488 & 62 \\
1887 & 399 & 622 & 223 \\
1888 & 386 & 793 & 407 \\
1889 & 432 & 766 & 334 \\
1890 & 406 & 703 & 297 \\
1891 & 371 & 721 & 350 \\
1892 & 399 & $475(a)$ & 76 \\
1893 & 449 & 599 & 150 \\
1894 & 575 & 664 & 149 \\
1895 & 489 & 691 & 202 \\
1896 & 540 & 667 & 127 \\
1897 & 507 & 704 & 197 \\
1898 & 562 & 768 & 206
\end{tabular}

(a) 1891 was een jaar van misoogst geweest.)

De uitwoeren bestaan tegenwoordig in normale jaren voor ongeveer de helft in granen.

1) Volgens een tabel samengesteld door Von Schulze-Gävernitz t. a. p. bl. 566 .

ECon. 1900. 
De tarwe-productie en uitvoer heeft in de laatste jaren bedragen ${ }^{1}$ ) Productie.

Uitvoer

in hectoliters.

$\begin{array}{llllll}1893 / 94 & . & . & . & 117.774 .000 & 30.450 .000 \\ 1894 / 95 & . & . & . & 154.135 .000 & 39.150 .000 \\ 1895 / 96 & . & . & . & 160.950 .000 & 50.750 .000 \\ 1896 / 97 & . & . & . & 140.000 .000 & 46.400 .000 \\ 1897 / 98 & . & . & . & 140.650 .000 & 40.600 .000 \\ 1898 / 99 & \text {. } & \text {. } & . & 146.849 .000 & 45.500 .000\end{array}$

In $1898 / 99$ was de productie verder

in hectoliters.

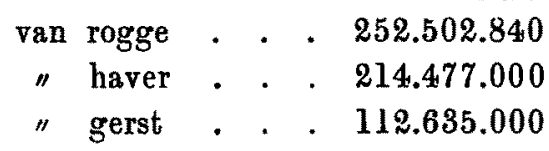

Zeer opmerkelijk zijn de volgende algemeene productiecijfers. ${ }^{2}$ ) Waarde in millioentallen francs $\left(2 \frac{2}{3} \mathrm{fr} .=1\right.$ roebel)

\begin{tabular}{|c|c|c|c|c|}
\hline & 1877 & 1887 & 1892 & 1897 \\
\hline Textiel-industrie & 791 & 1234 & 1547 & 2517 \\
\hline Hout-opbrengst & 44 & 68 & 88 & 273 \\
\hline Chemische producten & 28 & 57 & 93 & 158 \\
\hline Aardewerk & 54 & 77 & 85 & 219 \\
\hline Metaal-industrie & 237 & 299 & 431 & 826 \\
\hline
\end{tabular}

Productie der kolenmijnen ${ }^{3}$ )

in millioentallen $\mathrm{KG}$.

\begin{tabular}{|c|c|c|}
\hline 1877 & . & \\
\hline 1887 & 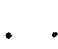 & \\
\hline 1892 & . & \\
\hline 1897 & & \\
\hline 1898 & & \\
\hline
\end{tabular}

1) Volgens Bourgarel. Economiste Européen. 2 Febr. 1900.

3) Ereneens aan Bourgarel ontleend.

3) Voor bijzonderheden omtrent de industrieele districten van Rusland zij hier verwezen o. m. naar W. Besobrasof. Etudes sur l'Economie nationale de la Russie. St. Petersburg 1883-86. M. Verstraete. La Russie industrielle. Parijs 1897. Dezelfde, L'Oural. Parijs. 1899; voorts naar de hoofdstukken over Rusland in de jaarlijks verschijnende Marché Financier van A. Raffalovich en naar talrijke mededeelingen van denzelden schrijver voortdurend verschijnende in L'Economiste Français, eindelijk en niet het minst naar het Bulletin Rnsse de Statistique financière et de Législation. 
Voor 1897 is de verdeeling der productie naar de verschillende districten, voor zooveel de vooruaamste dezer betreft, de volgende:

District. $\quad$ in duizendtallen K.G.

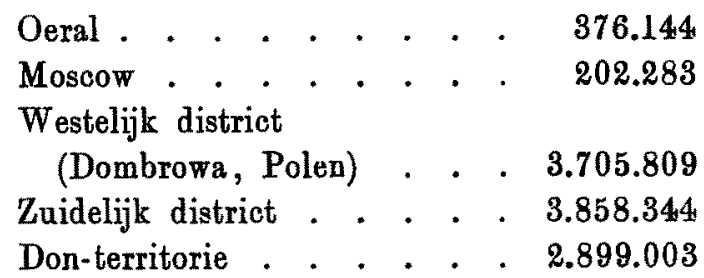

Productie van giet-ijzer in Pud's ( $\mathrm{Pud}=16^{38} \mathrm{KG}$.)

\begin{tabular}{|c|c|c|}
\hline 10 & & \\
\hline 890 & & \\
\hline & & 60. \\
\hline & 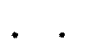 & \\
\hline 93 & & 777 \\
\hline & . & 80 \\
\hline & & 54 \\
\hline 16 & . & 98.452 .998 \\
\hline & & 113.785 .453 \\
\hline 00 & & 135.635 .51 \\
\hline
\end{tabular}

en $1^{\text {sto }}$ semester

1899 . . 81.551 .399

Ten aanzien van de voornaamste ijzer produceerende districten was de verdeeling als volgt:

Productiecijfers in duizendtallen Pud.

$$
\text { Oeral. }
$$

$1889 \quad 24.700$

$1890 \quad 27.700$

$1891 \quad 29.900$

$1892 \quad 30.600$

$1893 \quad 31.000$

$1894 \quad 32.700$

$1895 \quad 33.247$

$1896 \quad 35.457$

$1897 \quad 40.816$

$1898 \quad 43.539$

$1^{\text {the }}$ semester
Moscow.

5.107

5.753

6.177

6.430

7.172

7.700

7.680

8.226

10.351

11.016

Zuiden.

Polen.

8.468

5.380

13.417

7.4 .23

15.456

7.474

17.199

8.873

20.043

9.761

27.370

10.745

33.675

11.586

38.955

13.391

46.182

13.941

b'1.188

16.069

$1899 \quad 23.971$

8.020

38.492

9.043 
De productie van gewalst ijzer bedroeg in 1898 30.457.383 Pud, die van staal 69.928.325 Pud, tegen in 1885

$$
\begin{aligned}
& \text { gewalst ijzer. . . . . 22.117.284 Pud } \\
& \text { staal . . . . . . 11.776.277" }
\end{aligned}
$$

De productie van spoorstaven is van 1884 tot 1895 geweest. als volgt :

$\begin{array}{rrrrrr}1884 & 91.989 & 1888 & 64.314 & 1892 & 197.280 \\ 1885 & 94.717 & 1889 & 95.658 & 1893 & 237.301 \\ 1886 & 112.918 & 1890 & 173.038 & 1894 & 249.979 \\ 1887 & 87.941 & 1891 & 171.059 & 1895 & 302.189\end{array}$

Om zich rekenschap te geven van de beteekenis der tegenwoordige ijzer- en staalproductie van Rusland zal het niet zonder nut zijn de productie-cijfers van het land met die van andere landen te vergelijken. ${ }^{1}$ )

De wereld-productie van gietijzer is van 1870 tot 1898 vermeerderd van 12.019 Millioen KG.

$$
\text { tot } 36.350 " \text { " }
$$

In de eerste zeventiger jaren nam Rusland in deze productie den zevenden rang in; thans in de met meer dan 200 pCt. vermeerderde productie bekleedt het de vijfde plaats. De volgorde was in 1898 als volgt:

V. S. van Amerika met 11.962 Millioen KG.

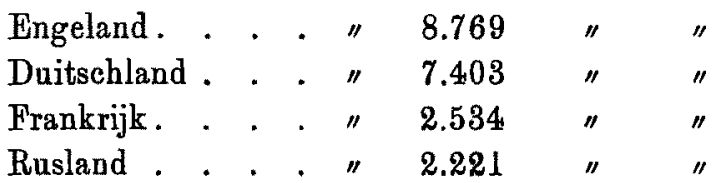

(gelijk 135.635.513 pud als boven vermeld).

Wat betreft de productie van staal, zoo nam Rusland in 1898 den vierden rang in. De volgorde was:

Ver. Staten. . . . met $37^{20}$ pCt. der wereld-productie

Duitschland . . . " $23^{50} "$ " " "

Engeland. . . . . "1901" " " " "

Rusland . . . . "5 59" " "

Petroleum productie.

De productie van ruwe olie (nafta) vermeerderde in Rusland $\operatorname{van} 1877$ tot 1898 als volgt:

1) Verg. E. Payen. Les nouveaux pays producteurs de métaux in L'Economiste français 1899. II. bl. 824-26. 
in millioentallen $\mathrm{KG}$.

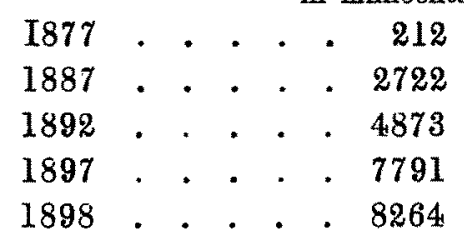

Dit laatste staat gelijk met ongeveer $504{ }^{5}$ millioen pud $=$ ongeveer 2208 millioen gallons, zijnde nog iets meer dan het productiecijfer van ruwe petroleum in Amerika, dat voor 1898 wordt opgegeven 2111 millioen gallons te hebben bedragen.

Het aandeelen-kapitaal der Russische naamlooze rennootschappen ten doel hebbende industrieele of handelsondernemingen - niet inbegrepen banken en spoorwegmaatschappijen - werd berekend op 1 Augustus 1899 ongeveer 2050 millioen roebels te bedragen. 1) En met inbegrip der buitenlandsche maatschappijen, die gemachtigd zijn hun bedrijf in Rusland uit te oefenen, ongeveer 2500 millioen roebels. ${ }^{2}$ )

Nog eene statistieke opgaaf tot besluit.

Volgens eene dezer dagen verschenen publicatie van de Société impériale économique de Saint-Petersbourg ${ }^{3}$ ) bestonden er in Ruslaud op 1 Januari 1894 44.545 openbare lagere scholen, waarvan 6651 in de steden en 37.894 op het platte land. Op 1260 na werden al deze scholen door den staat bekostigd. T'ot 1856 bestonden er slechte 4221 dergelijke scholen. Sedert 1868 is echter de oprichting krachtig ter haud genomen en aijn er jaarlijks ongeveer 1000 geopend.

Dr. Bijvauck schreef dezer dagen, de politieke gebeurtenissen der laatste weken besprekende: ${ }^{*}$ ) "Alleen Rusland dringt behoedzaam, zouder ophouden, zijn inacht verder voort over de landen die het voorbeschikt heeft tot zijn domein. Het onderwerpt Noord-Perzië aau ziju invloed, het verlangt zijn aandeel van Klein-Azië, het gaat afrekening houden met Turkije ... Dat alles rustig overlegd, stap voor stap, zeker. Het is de

1) Bulletin Russe no 4-6. 1899.

2) L. Raffalovich t. a. p. bl. 252.

3) Overgenomen door A. Neymurck in Le Rentier van 7 April 11.

1) Buitenlandsch Overzicht «Maartsche buien* Gids. April afl. 
periode voorbij van avontuurlijke politiek, het voelt zich te groot, het laat zich niet storen door Maartsche buien en nukken." Meu kau inderdaad niet dan bewondering en ontzag hebben voor dit politiek beleid. Maar nog meer dan op het politiek terrein blijkt die grootheid en dat rustig, behoedzaam streven naar ontwikkeling en vooruitgang op het economisch terrein. En terwijl daarin voor Europa een groote waarborg bestaat dat door Rusland de wereldvrede niet wordt bedreigd, is er voor het land zelf de hechtste grondslag in gelegen voor zijn bloei eu welvaart.
Amsterdam.
G. M. Borssevain. 